\title{
INFLUENCE OF BEAK TRIMMING AND STOCKING DENSITY ON PERFORMANCE AND EGG QUALITY OF LAYING HENS IN A TROPICAL ENVIRONMENT
}

\author{
H.H.M. Hassanien and A.A.A. Abdel-Wareth \\ Department of Animal and Poultry Production, Faculty of Agriculture, South Valley University, \\ 83523 Qena, Egypt
}

\section{SUMMARY}

Influence of beak trimming and stocking density on performance and egg quality of laying hens in a tropical environment was studied in 189 laying hens (Hy-Line) at 38 weeks of age. All birds divided into three groups. First group of the birds were kept with intact beaks as a control. Second group about $3 \mathrm{~mm}$ of the upper and the lower part of the beak were removed by a hot blade at 38 weeks of age. Third group about $3 \mathrm{~mm}$ of the upper and the lower part of the beak were removed by a hot blade at 38 weeks of age and again at 50 weeks of age. Each group was subdivided into three stocking density 6, 7 or 8 birds from each three replicates. Egg mass, feed consumption and Feed conversion ratio (FCR) were recorded weekly for 16 weeks experimental periods. In addition egg production and egg weight were recorded continuously for 16 weeks of age. There were no significant difference between the beak trimmed and control birds for egg production, egg weight, egg mass, feed intake and FCR for the experimental period. Egg mass and feed intake were significantly higher and FCR was significantly lower in 6 birds stocking density in trimmed and control group. Interaction effects of stocking density and the beak-trimmed hens showed a significant effect in egg production, egg mass, egg weight, feed intake and FCR from 38 to 54 weeks of age. There were significant difference between the beak trimmed and stocking density on some egg quality measurements at 54 weeks of age. It has been concluded that moderate beak trimming in laying hens has only a short term effect on feed intake, some egg productions and egg quality traits.

\section{Keywords: Laying hens, beak trimming, density, performance}

\section{INTRODUCTION}

In Egypt, beak trimming is done as a last resort where alternatives are considered not to be possible or appropriate. The reason for beak trimming is to reduce the risk of injurious pecking that can lead to significant feather and skin damage, cannibalism, pain and suffering, leading sometimes to death (excess of 20\%). Once started, problems are difficult to resolve, leading to chronic, often irreversible, injury and damage (FAWC, 2007).

Importantly, data show that removing $50 \%$ or less of the beak of chicks can prevent the formation of neuromas and allow regeneration of keratinized tissue to prevent deformed beaks and therefore positively affect the quality of life of birds during their lifetime (Kuenzel, 2007). Kuenzel also reviewed that other factors have been investigated to minimize feather pecking include nutritional deficiencies, light intensity, genetic predisposition, environmental enrichment, abrasive devices, fitted devices, and stock wound sprays.

To date, however, the most effective means to prevent the risk of injurious pecking and cannibalism is to beak trim flocks of birds. The benefits of beak trimming are clear in mature birds, as reflected by reduced pecking damage and cannibalism and the increased production characteristics (Glatz, 2005). Martinec et al. (2002) found that concluded that moderate beak trimming in laying hens has only a short term effect on feed intake and performance traits.

Egg laying strains of chickens can be kept in smaller group sizes in caged systems, cannibalism is reduced (Appleby and Hughes, 1991). Various studies reporting effects of beak trimming on performance of laying hens and the results are contradictory (Martinec et al., 2002: Kuenzel, 2007). The relationship between the beak trimming and socking density has received relatively little knowledge. Therefore, the objectives of this study were to evaluate the effects of interaction of beak trimming and different stocking density on egg production and egg quality of laying hens kept in cages in tropical environment.

\section{MATERIALS AND METHODS}

\section{Experimental materials and procedures}

The present study was carried out at the Poultry Farm in the Department of Animal Production, Faculty of Agriculture, South Valley University. One hundred and eighty nine 38-wkold Hy-line hens were housed in a tropical environmentally controlled cage system. All 
birds divided into three groups. First group of the birds were kept with intact beaks as a control. Second group about $3 \mathrm{~mm}$ of the upper and the lower part of the beak were removed by a hot blade at 38 weeks of age. Third group about 3 $\mathrm{mm}$ of the upper and the lower part of the beak were removed by a hot blade at 38 weeks of age and again at 50 weeks of age. Each group was subdivided into three stocking density 6 (560 $\left.\mathrm{cm}^{2} / \mathrm{hen}\right), 7\left(480 \mathrm{~cm}^{2} / \mathrm{hen}\right)$ or $8\left(420 \mathrm{~cm}^{2} / \mathrm{hen}\right)$ birds from each three replicates.

The managements were similar for all groups. The indoor temperature was about $24^{\circ} \mathrm{C} \pm 2^{\circ} \mathrm{C}$ during the experimental period and the humidity was about $50 \%$. The photoperiod was 16L: $8 \mathrm{D}$ throughout the experiment. The composition and calculated analysis of the experimental diet are shown in Table 1. Feed and water were $a d$ libitum.

Body weights of the hens were determined at the beginning (1750 \pm 0.230$)$. Daily records of egg production and feed consumption, and monthly records of egg weight were kept and were summarized as hen-day egg production, egg mass, and FCR on a monthly basis.

The parameters relative to egg quality were evaluated at 54 weeks of age. Nine eggs were randomly collected per treatment to determine these parameters. The collected eggs were weighed $( \pm 0.01 \mathrm{~g})$, and each egg was then exposed to a pressing force by using an eggshell strength meter. On breaking, the egg contents were poured. The Haugh unit (HU) was measured for the internal quality of the eggs. The height, correlated with the weight, determines the HU. The higher the number, the better the quality of the egg (fresher, higher quality eggs have thicker whites). The test was introduced by Haugh (1937) and is considered the most significant measure of egg quality. Shell, Albumin and yolk percentage were calculated.

\section{Statistical analysis:}

Data were analyzed using a two way analysis of variance (ANOVA) to analyze the differences between treatment groups using SAS (SAS, 2005) General Linear Models procedures. The statistical model used for analyzing data obtained was:

Yik $=\mathrm{U}+\mathrm{Ti}+\mathrm{Dj}+\mathrm{TDij}+\mathrm{EijK}$

Where:-

Yik = observed value of the concerned trait.

$\mathrm{U}=$ observed mean for the concerned trait.

$\mathrm{D}=$ the fixed effect due to peak trimming

$\mathrm{Fj}=$ the fixed effect due to stocking density

$\mathrm{DiFj}=$ the fixed effect due to trimming and density.

Eijk $=$ Random error.

The differences among the means of individual treatments were tested with Duncan multiple range test (Duncan, 1955) P values less than 0.001 were expressed as ' $<0.001$ ' rather than the actual value.

\section{RSULTS}

\section{Egg production, egg weight and egg mass:}

Effect of peak trimming, density and their interaction on egg production, egg weight and egg mass is presented in Table (2). There were no significant differences observed between the beak trimmed and non beak trimmed hens on egg production, egg weight and egg mass during the experimental period. Egg mass was significantly higher with the decreasing stocking density. Interaction effects of stocking density and the beak-trimmed hens showed a significant effect in egg production, egg mass and egg weight from 38 to 54 weeks of age. $560 \mathrm{~cm} 2$ cage area per hen is better than $420 \mathrm{~cm} 2$ cage area per hen, because increasing cage area enhanced their performance and welfare during the laying period.

\section{Feed intake and feed conversion ratio:}

Effect of peak trimming, density and their interaction on feed intake and FCR is presented in Table (2). There were no significant differences observed between the beak trimmed and non beak trimmed hens on feed intake and FCR during the experimental period. Feed intake was significantly higher and FCR was significantly lower with the decreasing stocking density. Interaction effects of stocking density and the beak-trimmed hens showed a significant effect in feed intake and FCR from 38 to 54 weeks of age.

\section{Egg quality:}

Effect of peak trimming, density and their interaction on egg quality is presented in Table 3. Shell\%, albumin \%, yolk\%, and shell thickness were statistically significant among trimming groups. Shell\%, yolk\% and shell thickness were significantly higher in trimming groups than control. Only albumin\% was significantly higher in control than trimming groups. Shell\%, albumin $\%$, yolk\%, and shell thickness were statistically significant among stocking density groups. No significant differences were observed in Haugh units and shell strength among density and trimming groups. There were significant different on the egg quality indices such as shell\%, albumin $\%$, yolk\%, shell strength and shell thickness in interaction effects of stocking density and trimming treatments. No significant differences were observed for Haugh unis among treatments.

\section{DISCUSSION}

The improvements in some parameters such as egg production, performance and egg quality 
of laying hens were observed in trimming birds and small density (table 2 and 3 ). This was mainly due to beak trimming remains the most effective way to prevent cannibalism, although cages with small group of hens slightly reduced the incidence and that further development and optimization performance and egg quality of laying hens.

The effects of beak trimming on egg production have often been the subject of investigations by researchers. While some (Guesdon et al., 2006; and Onbaşılar et al., 2009) have found increased rates of egg production as a benefit of trimming, others have reported nonsignificant effects (Carey and Lassiter, 1995; Gentle et al., 1997). Feed intake and feed conversion ratios were lower in small hens group (420 cm2/hen) than larger hen group (Table 2) Generally, the present result was agreement with Davis et al. (2004) showed that feed consumption was lower in group of $361 \mathrm{~cm} 2 / \mathrm{hen}$ than that of $484 \mathrm{~cm} 2 /$ hen. Contrary Maizama and Adams (1994) reported that FCR was better in untrimmed group than trimmed groups at 20-40 wk of age. This difference may be due to the trimming age. Feed conversion ratio was affected by birds of number/ cage area. Increasing cage area had a positive effect on feed conversion ratio. No difference in egg production was observed throughout the production period between the beak-trimming or stocking density treatments similar to the findings of Glatz (2009). Contrary to Onbaşılar et al. (2009) egg production was lower in cage area of 323 $\mathrm{cm} 2 /$ hen $(\mathrm{P}<0.05)$. Some researchers (Quart and Adams, 1982; and Onbaşılar and Aksoy, 2005) reported the same results. However laying hens group/cage area effect egg mass and didn't affect egg weight. Decreased cage area per hen enhanced the egg mass. This may be due to the lower egg production of this group. Some researchers (Davami et al., 1987; and Onbaşılar et al., 2009) reported the similar results. However other researchers (Cunningham and Ostrander, 1982; Quart and Adams, 1982; and Onbaşılar and Aksoy, 2005) reported contrary results. These differences may be due to the using different genotype, age and cage systems among researches (Onbaşılar et al., 2009).

The egg quality indices such as shell\%, albumin\%, yolk\%, shell strength and shell thickness were statistically significant among trimming groups and stocking density (Table 3 ). In contrast shell breaking strength, shape index and shell thickness have not statistically significant among trimming groups (Onbaşılar et $a l .$, 2009). Similarly Ruszler (1994) reported that production variables were not significant among groups of beak trimming. Insufficient information has available on the interaction effects of beak trimming and stocking density on egg production and egg quality.

\section{CONCLUSION}

Egg production, feed intake and FCR were improved in birds kept in low stocking density with or without beak trimming And also different trimming age in the rearing period isn't creating the diversity about examined parameters in the laying period. $580 \mathrm{~cm} 2$ cage area per hen is better than $420 \mathrm{~cm} 2$ cage area per hen, because increasing cage area enhanced their performance and welfare during the laying period. More researches are needed to reduce the risk of laying hens pecking behaviour in enriched cages or noncage systems (free range, barn or organic).

\section{ACKNOWLEDGMENT}

This research was funded by South Valley University. The authors wish to express their appreciation to the university.

\section{REFERENCES}

Appleby, M.C. and G.S. Hogarth, 1991. Welfare of laying hens in cages and alternative systems: Environmental, physical and behavioural aspects. World's Poult. Sci. 47:109-128.

Carey, J.B. and B.W. Lassiter, 1995. Influences of age at final beak trim on the productive performance of commercial layers. Poult. Sci. 74:615-619.

Cunningham, D.L., 1992. Beak trimming effects on performance, behavior and welfare of chickens. J. Appl. Poult. Res. 1:129-134.

Davami, A., M.J. Wineland, W.T., Jones, R.A. Ilardi and R.A. Peterson, 1987. Effects of population size, floor space and feeder space upon productive performance, external appearance and plasma corticosterone concentration of laying hens. Poult. Sci. 66:251-257.

Davis, G.S., K.E. Anderson and D.R. Jones, 2004. The effects of different beak trimming techniques on plasma corticosterone and performance criteria in Single Comb White Leghorn hens, Poult. Sci. 83:1624-1628.

Duncan, D.B., 1955. Multiple range and multiple F-test. Biometrics 11:1-42.

FAWC, 2007. Opinion on Beak Trimming of Laying Hens.

http://www.fawc.org.uk/pdf/enrichedcages.pdf.

Gentle, M.J., B.O., Hughes, A. Fox and D. Waddington, 1997. Behavioural and anatomical consequences of two beak trimming methods in 1- and 10- day old chicks, Br. Poult. Sci. 38:453-463. 
Glatz, P.C., 2009. Effect of hot blade and infrared beak trimming on beak condition, production and mortality of laying hens. Proceedings of 8th Poultry Welfare Symposium, Cervia, Italy, pp. 24.

Glatz, P.C., 2005. Poultry Welfare Issues: Beak Trimming Nottingham University Press, Nottingham, United Kingdom.

Guesdon V., A. M. Ahmed, S., J.M. Faure and Y. Nys, 2006. Effects of beak trimming and cage design on laying hen performance and egg quality. Br. Poult. Sci., 47:1-12.

Haugh. R.R., 1937. The Haugh unit for measuring egg quality. U.S. Egg Poultry Magazine, No. 43:552-555.

Khajali, F., E.A., Khoshouie, S. K., Dehkordi and M. Hematian, 2008. Production Performance and Egg Quality of Hy-Line W36 Laying Hens Fed Reduced-Protein Diets at a Constant Total Sulfur Amino Acid:Lysine Ratio. J. Appl. Poult. Res. 17:390-397.

Kuenzel, W.J., 2007. Neurobiological basis of sensory perception: Welfare implications of beak trimming. Poult. Sci. 86:1273-1282.

Ma1zama, D.G. and A.W., Adams, 1994. Effect of beak trimming, blade temperature and age at beak trimming on performance of two strains of egg layers, J. Appl. Poult. Res. 3:69-73.

Martinec, V., W. Bessei and K. Reiter, 2002. The influence of beak trimming on feeding activity and pecking of a bunch of feathers in 14 months old laying hens. Arch. Geflügelk., 66:193-200.

Onbaşılar, E.E., E.D. Şahnur, Z. Kahraman, E. Karademir and S. Demir, 2009. The influence of different beak trimming age on performance, $\mathrm{H}-\mathrm{L}$ ratio and antibody production to SRBC in laying hens. Trop. Anim. Health Prod. 41:221-227.

Onbaşılar, E.E. and T., Aksoy, 2005. Stress parameters and immune response of layers under different cage floor and density conditions, Livest. Prod. Sci. 95:255-263.

Quart, M. D. and A. W. Adams, 1982. Effects of cage design and bird density on layers. 1. Productivity, feathering and nervousness, Poult. Sci. 61:1606-1613.

Ruszler, P.L., 1994. Comparisons of no beak trimming and two commercial beak trimming regimens under light controlled conditions. Poult. Sci. 73 (Suppl 1): 159 (Abstr).

SAS Institute, 2005. User's Guide: Statistics. Version 9.1. SAS Institute, Inc., Cary, NC, USA. 
Table 1. Composition and calculated analysis of the experimental diet

\begin{tabular}{lc}
\hline \multicolumn{1}{c}{ Ingredients } & g/kg \\
\hline Yellow corn & 609 \\
Soybean meal $(44 \%)$ & 216 \\
Corn gluten meal $(60 \%)$ & 60 \\
Vit\&Min. premix* & 3.0 \\
Wheat bran & 4.5 \\
Dicalcium phosphate & 13.6 \\
Calcium carbonate & 89.5 \\
Salt & 4.0 \\
DL-methionine & 0.4 \\
Total & 1000 \\
Calculated analysis: & \\
\hline ME, Kcal/Kg & 2766.00 \\
Crude Protein, $(\mathrm{g} / \mathrm{kg})$ & 184.5 \\
Crude fiber, $(\mathrm{g} / \mathrm{kg})$ & 26.8 \\
Crude fat, $(\mathrm{g} / \mathrm{kg})$ & 27.8 \\
Ca, $(\mathrm{g} / \mathrm{kg})$ & 38.7 \\
P $($ Available, $\mathrm{g} / \mathrm{kg})$ & 3.8 \\
Lysine, $(\mathrm{g} / \mathrm{kg})$ & 8.5 \\
Methionine, $(\mathrm{g} / \mathrm{kg})$ & 4.0 \\
Methionine+Cystine $(\mathrm{g} / \mathrm{kg})$ & 6.5 \\
\hline
\end{tabular}

*Vitamins and minerals premix provided per kilogram of the diet: Vit A, 1000 IU; D3 2000 ICU; Vit E, 10 mg; Vit K, 1mg; B1, $10 \mathrm{mg}$; B2, $5 \mathrm{mg}$; B6, $1500 \mathrm{mg}$; B12, 10mg Pantothenic acid, $10 \mathrm{mg}$; Nicotinic acid, $30 \mathrm{mg}$; Folic acid, 1mg; Biotin, $50 \mathrm{mcg}$; Chloride, $500 \mathrm{mg}$; copper, $10 \mathrm{mg}$; iron, $50 \mathrm{mg}$; Manganese, $60 \mathrm{mg}$; Zinc, 50mg, and selenium, $0.1 \mathrm{mg}$.

Table 2. Effects of peak trimming, stocking density and their interactions on performance of laying hens

\begin{tabular}{|c|c|c|c|c|c|}
\hline Treatments & $\begin{array}{c}\text { Egg } \\
\text { production } \%\end{array}$ & $\begin{array}{l}\text { Egg mass } \\
\text { g/bird/day }\end{array}$ & $\begin{array}{c}\text { Egg weight } \\
\text { (g) }\end{array}$ & $\begin{array}{c}\text { Daily FI } \\
(\mathrm{g})\end{array}$ & FCR \\
\hline \multicolumn{6}{|l|}{ Trimming } \\
\hline Control & 66.52 & 45.86 & 59.15 & 111 & 1.887 \\
\hline Trimming once & 71.35 & 49.79 & 59.78 & 117 & 1.962 \\
\hline Trimming twice & 74.29 & 51.82 & 59.90 & 114 & 1.918 \\
\hline SEM & 1.151 & 1.041 & 0.277 & 2.172 & 0.036 \\
\hline P-Value & 0.158 & 0.113 & 0.729 & 0.362 & 0.507 \\
\hline \multicolumn{6}{|l|}{ Stocking Density } \\
\hline 6 birds & 69.64 & $54.47 \mathrm{a}$ & 60.10 & $125 \mathrm{a}$ & $1.658 \mathrm{a}$ \\
\hline 7 birds & 74.37 & $51.11 \mathrm{a}$ & 58.84 & $118 \mathrm{a}$ & $2.015 \mathrm{~b}$ \\
\hline 8 birds & 68.15 & $41.90 \mathrm{~b}$ & 59.93 & $99 \mathrm{~b}$ & $2.094 \mathrm{~b}$ \\
\hline SEM & 1.282 & 0.792 & 0.221 & 0.801 & 0.013 \\
\hline P-Value & 0.282 & 0.001 & 0.056 & 0.001 & 0.001 \\
\hline \multicolumn{6}{|l|}{ Interaction } \\
\hline$\overline{\text { Control }+6}$ birds & $79.36 \mathrm{a}$ & $47.25 \mathrm{c}$ & $59.45 \mathrm{~cd}$ & $102 \mathrm{~d}$ & $1.722 \mathrm{a}$ \\
\hline Control +7 birds & $76.31 \mathrm{ab}$ & $53.37 \mathrm{~b}$ & $59.91 \mathrm{bcd}$ & $116 \mathrm{c}$ & $1.940 \mathrm{~b}$ \\
\hline Control +8 birds & $69.68 \mathrm{c}$ & $55.37 \mathrm{ab}$ & $60.10 \mathrm{bc}$ & $128 \mathrm{a}$ & $2.142 \mathrm{~d}$ \\
\hline Trimming once +6 birds & $75.84 \mathrm{bc}$ & $46.54 \mathrm{c}$ & $61.36 \mathrm{a}$ & $106 \mathrm{~d}$ & $1.733 \mathrm{~d}$ \\
\hline Trimming once +7 birds & $80.91 \mathrm{a}$ & $55.79 \mathrm{ab}$ & $59.24 \mathrm{~d}$ & $123 \mathrm{ab}$ & $2.084 \mathrm{ab}$ \\
\hline Trimming once +8 birds & $73.43 \mathrm{ab}$ & $59.07 \mathrm{a}$ & $60.40 \mathrm{~b}$ & $125 \mathrm{ab}$ & $2.083 \mathrm{ab}$ \\
\hline Trimming twice +6 birds & $79.36 \mathrm{a}$ & $48.81 \mathrm{c}$ & $61.26 \mathrm{a}$ & $105 \mathrm{~d}$ & $1.727 \mathrm{a}$ \\
\hline Trimming twice +7 birds & $81.16 \mathrm{a}$ & $57.04 \mathrm{ab}$ & 60.14 bc & $123 \mathrm{~b}$ & $2,049 \mathrm{c}$ \\
\hline Trimming twice +8 birds & $69.42 \mathrm{c}$ & $55.95 \mathrm{ab}$ & $60.69 \mathrm{ab}$ & $124 \mathrm{ab}$ & $2,050 \mathrm{~b}$ \\
\hline SEM & 0.622 & 0.465 & 0.095 & 0.711 & 0.012 \\
\hline P-Value & 0.001 & 0.001 & 0.001 & 0.001 & 0.001 \\
\hline
\end{tabular}

Values in each column are means for 3 replicates of each treatment

SEM: Stander error of means

FI: Feed intake 
Table 3. Effects of peak trimming, stocking density and their interactions on egg quality of laying hens

\begin{tabular}{|c|c|c|c|c|c|c|}
\hline Treatments & $\begin{array}{c}\text { Yolk } \\
\% \\
\end{array}$ & $\begin{array}{c}\text { Albumin } \\
\%\end{array}$ & $\begin{array}{c}\text { Shell } \\
\%\end{array}$ & $\mathrm{HU}$ & $\begin{array}{c}\text { Shell thickness } \\
(\mathrm{mm})\end{array}$ & $\begin{array}{l}\text { Shell strength } \\
(\mathrm{kg} / \mathrm{cm} 2)\end{array}$ \\
\hline \multicolumn{7}{|l|}{ Trimming } \\
\hline Control & $27.50 \mathrm{~b}$ & $60.12 \mathrm{a}$ & $12.37 \mathrm{~b}$ & 73.48 & $0.354 \mathrm{~b}$ & 2.98 \\
\hline Trimming once & $28.54 \mathrm{ab}$ & $57.89 \mathrm{~b}$ & $13.56 \mathrm{a}$ & 73.90 & $0.371 \mathrm{a}$ & 3.07 \\
\hline Trimming twice & $28.91 \mathrm{a}$ & $57.87 \mathrm{~b}$ & $13.20 \mathrm{a}$ & 74.76 & $0.365 \mathrm{a}$ & 3.01 \\
\hline SEM & 0.278 & 0.411 & 0.178 & 0.299 & 0.003 & 0.086 \\
\hline P-Value & 0.016 & 0.007 & 0.007 & 0.874 & 0.023 & 0.762 \\
\hline \multicolumn{7}{|l|}{ Stocking Density } \\
\hline 6 birds & $29.35 \mathrm{a}$ & $56.88 \mathrm{~b}$ & $13.75 \mathrm{a}$ & 74.18 & $0.372 \mathrm{a}$ & 2.93 \\
\hline 7 birds & $28.16 \mathrm{ab}$ & $59.29 \mathrm{a}$ & $12.54 \mathrm{~b}$ & 74.14 & $0.363 \mathrm{ab}$ & 3.06 \\
\hline 8 birds & $27.45 \mathrm{~b}$ & $59.70 \mathrm{a}$ & $12.84 \mathrm{~b}$ & 73.14 & $0.356 \mathrm{~b}$ & 3.06 \\
\hline SEM & 0.245 & 0.453 & 0.423 & 0.765 & 0.254 & 0.089 \\
\hline P-Value & 0.085 & 0.027 & 0.010 & 0.215 & 0.007 & 0.902 \\
\hline \multicolumn{7}{|l|}{ Interactions } \\
\hline Control +6 birds & $26.94 \mathrm{~b}$ & $60.79 \mathrm{a}$ & $12.26 \mathrm{~b}$ & 73.80 & $0.352 \mathrm{~b}$ & $3.24 \mathrm{ab}$ \\
\hline Control +7 birds & $27.60 \mathrm{~b}$ & $59.95 \mathrm{a}$ & $12.30 \mathrm{~b}$ & 73.77 & $0.356 \mathrm{~b}$ & $2.87 \mathrm{ab}$ \\
\hline Control +8 birds & $27.81 \mathrm{~b}$ & $59.61 \mathrm{a}$ & $12.56 \mathrm{~b}$ & 72.88 & $0.354 \mathrm{~b}$ & $2.84 \mathrm{ab}$ \\
\hline Trim once +6 birds & $27.80 \mathrm{~b}$ & $59.48 \mathrm{a}$ & $12.70 \mathrm{~b}$ & 72.67 & $0.362 \mathrm{~b}$ & $3.00 \mathrm{ab}$ \\
\hline Trim once +7 birds & $28.36 \mathrm{ab}$ & $58.82 \mathrm{abc}$ & $12.80 \mathrm{~b}$ & 74.21 & $0.361 \mathrm{~b}$ & $3.56 \mathrm{a}$ \\
\hline Trim once +8 birds & $29.46 \mathrm{ab}$ & $55.36 \mathrm{c}$ & $15.16 \mathrm{a}$ & 74.83 & $0.392 \mathrm{a}$ & $2.58 \mathrm{~b}$ \\
\hline Trim twice +6 birds & $27.60 \mathrm{~b}$ & $58.82 \mathrm{abc}$ & $13.56 \mathrm{~b}$ & 75.03 & $0.354 \mathrm{~b}$ & $2.76 \mathrm{ab}$ \\
\hline Trim twice +7 birds & $28.36 \mathrm{ab}$ & $59.12 \mathrm{ab}$ & $12.50 \mathrm{~b}$ & 74.44 & $0.373 \mathrm{ab}$ & $3.38 \mathrm{ab}$ \\
\hline Trim twice +8 birds & $30.77 \mathrm{a}$ & $55.68 \mathrm{bc}$ & $13.54 \mathrm{~b}$ & 74.83 & $0.369 \mathrm{~b}$ & $3.38 \mathrm{ab}$ \\
\hline SEM & 0.278 & 0.482 & 0.178 & 0.299 & 0.002 & 0.086 \\
\hline P-Value & 0.047 & 0.013 & 0.001 & 0.534 & 0.001 & 0.023 \\
\hline
\end{tabular}

Values in each column are means for 9 replicates of each treatment SEM: Stander error of means

HU: Haugh unit 
تأثير قص المنقار وكثافة الطيور على الأداء الانتاجي و جودة البيض لاجاج البياض في بيئة استوائية حسام حسين محمد حسانين و احمد ابويكر عبدالمنعم عبدالوارث قسم الإتتاج الحيواني والدواجن، كلية الزراعة، جامعة جنوب الوادي

أجريت هذه الدراسة لتقيم تأثير قص المنقار وكثافة العددية على الأداء الانتاجي و جودة البيض لاجاج البياض في بيئة استو ائية .

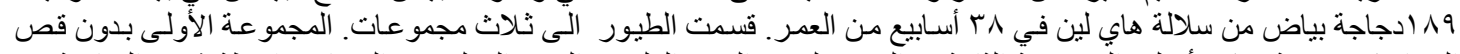

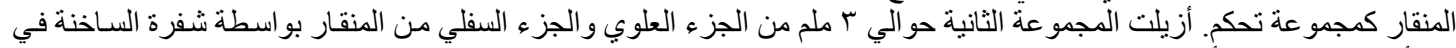

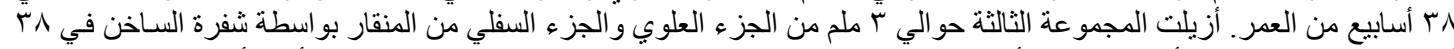

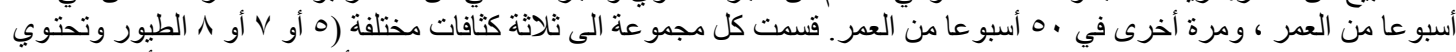

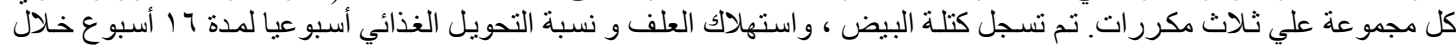

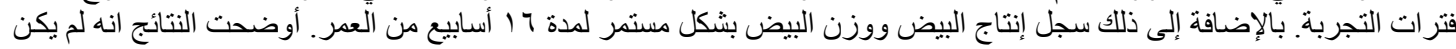

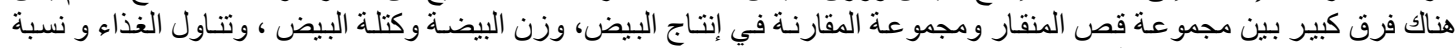

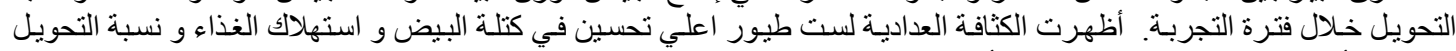

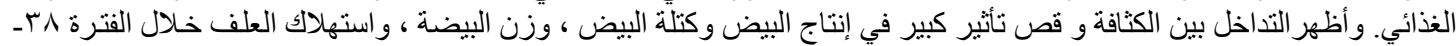

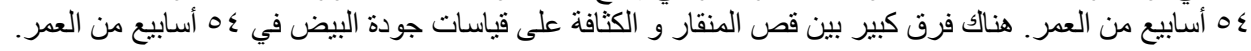

